\title{
Long memory in stock returns: Evidence from the Eastern European markets
}

\author{
Rui Dias ${ }^{1}$, Paula Heliodoro ${ }^{2, *}$, Paulo Alexandre ${ }^{2}$, Hortense Santos ${ }^{2}$, and Ana Farinha ${ }^{2}$ \\ ${ }^{1}$ School of Business and Administration, Polytechnic Institute of Setúbal, Portugal and CEFAGE-UE, \\ IIFA, University of Évora, Portugal \\ ${ }^{2}$ School of Business and Administration, Polytechnic Institute of Setúbal, Portugal
}

\begin{abstract}
This essay aims to analyze the impact of the 2020 global pandemic on the memory properties of the Eastern Europe stock markets, from the period between 1 January 2016 to 2 September 2020, the sample was divided in two subperiods: 1 January 2016 to 30 August 2019 (before Covid 19) and 2 September 2019 to 2 September 2020 (after Covid 19). To perform this analysis, different approaches were undertaken to analyze whether if: (i) the global pandemic (Covid-19) accentuated the exponents Detrended Fluctuation Analysis (DFA) and the Detrended CrossCorrelation Analysis ( $p D C C A$ ) in the Eastern European stock markets?. The daily returns do not have normal distributions, they have negative asymmetries, leptocubtic, and also exhibit conditional heteroscedasticity. The exponents Detrended Fluctuation Analysis (DFA), during the Covid19 period, range from 0.64 to 0.75 , showing significant long memories in all markets, except for the SLOVAKIA market (0.45). When we compared the 2 subperiods, we found that 41 pairs of markets have cross-correlation coefficients without trend ( $\lambda_{\text {DCCA }}$ ) strong (out of 45 possible), and 4 pairs of markets decreased the rhoDCCA in particular the markets ESTONIASLOVAKIA, LITHUANIA-SLOVAKIA, HUNGARY-SLOVAKIA, POLAND-SLOVAKIA. These findings show that the assumption of the market efficiency hypothesis may be in question, since the prediction of market movement can be improved if we consider the out-of-lag movements of the other markets, enabling the occurrence of arbitrage operations and some difficulties in portfolio diversification.
\end{abstract}

Keywords: Eastern European markets; long memories; arbitration; portfolio diversification.

\section{Introduction}

International financial markets have seen a succession of major setbacks in recent months, triggered by Covid-19, followed by a series of collapses, the oil war, and currency fluctuations. The economic turbulence associated with the coronavirus pandemic in 2019-

* Corresponding author: paula.heliodoro@esce.ips.pt 
2020 has serious repercussions on financial markets, notably on the stock, bond and commodity markets (including crude oil and gold). The main events were an oil price war between Russia and Saudi Arabia after an OPEC agreement was not reached, which led to the collapse of oil prices, and a significant drop in stock markets in March 2020 [1].

Financial instability is a very important factor for society since a financial crisis or a stock market crash can directly or indirectly affect the level of economic well-being of the inhabitants of a country. If a given stock market is strongly linked to the stock market of another country, the financial stability of the former depends in part on the financial stability of the second. Thus, the occurrence of significant causation between markets may question the diversification of portfolios [2].

Statistical physicists began to analyze financial data, creating an interdisciplinary research area called Econophysics [3]. To answer the research question, we will use the Detrended Fluctuation Analysis (DFA) methodology, and Zebende's Detrended CrossCorrelation Analysis (DCCA) [4]. DFA is used to analyze the dependency pattern of a given time series and is typically identified as a way to study the level of efficiency of financial markets. While $D F A$ analyzes the behavior of individual time series, rhoDCCA will be applied to analyze the far-reaching correlations between central European stock markets.

This essay aims to analyze the memory properties of eastern European stock markets from 1 January 2016 to 2 September 2020. To perform this analysis, different approaches were undertaken to analyze whether: (i) the global pandemic (Covid-19) accentuated the exponents Detrended Fluctuation Analysis (DFA) and the Detrended Cross-Correlation Analysis ( $p D C C A)$ in the Eastern European stock markets)?. The results suggest that the exponents Detrended Fluctuation Analysis (DFA) exhibit long memories, which may show some predictability in these regional markets. However, despite our findings, the hypotheses of anomic profitability have not been tested without incurring additional risk. The cross-correlation coefficients trendless $\lambda_{\text {DCCA }}$ show 41 pairs of markets with strong rhoDCCA $(\cong 0.666 \rightarrow \cong 1.000)$. The Estonia-Slovakia, Lithuania-Slovakia, HungarySlovakia, Poland-Slovakia markets decreased rhoDCCA. These findings show that the stock markets analyzed have high $r h o D C C A$ levels, which may question the hypothesis of portfolio diversification.

This essay adds two main contributions to the literature. The first contribution concerns the study of risk diversification in eastern European markets. As far as we know there are studies that have analyzed risk diversification in these regional markets, namely the authors Filipovski and Tevdovski [5], Ferreira [6], Muharam, Mawardi, Arfinto, and Najmudin [7], Moagar-Poladian, Clichici, and Stanciu [8], but the research questions, the sample, and the approach were different from those followed in this paper.

The second contribution is econophysical in nature, due to the comparative models Detrended Fluctuation Analysis (DFA) and Detrended Cross-Correlation Analysis $(p D C C A)$ that have the possibility of evaluating correlations in the context of nonstationarity. DFA is an analysis method that examines temporal dependence on nonstationary data series. This technique by assuming that time series are non-stationary avoids spurious results when the analysis focuses on the relationships of the data series in the long 
term. Zebende's trendless cross-correlation coefficient ( $p D C C A)$ [4] is a method for quantifying the level of cross-correlation between two non-stationary time series.

In terms of structure this test is organized in 5 sections. Section 1 is represented by the current introduction. Section 2 presents a Literature Review regarding the presence of long memories in international stock markets. Section 3 describes the data and methodology. Section 4 contains the results. Finally, section 5 presents the general conclusions of the work.

\section{Literature Review}

The theme on the efficient market hypothesis (EMH) has motivated other studies to analyze the implications in the market efficiency hypothesis, according to which the current price of assets reflects all available information at a given time, and the price adjusts rapidly as new and unforeseen information comes to market. The hypothesis of reversal of the mean, also called negative series correlation, has been interpreted as an efficient correction mechanism in developed markets and a sign of a speculative bubble in emerging financial markets [9].

Nisar and Hanif [10], Mehla and Goya [11], El Khamlichi, Sarkar, Arouri, and Teulon [12], Li, Nishimura, and Men [13], tested the random walk hypotheses in asian markets. Nisar and Hanif [10] show that South Asian stock markets reject the hypothesis of random walk evidencing (in) market efficiency in its weak form. Mehla and Goya [11] examined india's stock market, showing that the market does not show the characteristics of random walk and, as such, is not efficient in weak form. El Khamlichi, Sarkar, Arouri, and Teulon [12] suggest that Islamic indices have the same level of (in)efficiency as benchmarks but MSCI and FTSE indices are less inefficient. Li, Nishimura, and Men [13] examined the fractal dimensions of 30 stock exchanges from 2006 to 2013, the authors argue that most markets are efficient, under the assumption of non-arbitration.

Ngene, Tah, and Darrat [14], Ali, Shahzad, Raza, and Al-Yahyaee [15], Pernagallo and Torrisi [16] investigated whether international markets follow the random walk hypothesis. Ngene, Tah, and Darrat [14] examined 18 emerging markets in the presence of multiple unscheduled and successive structural breakdowns. When single break tests are used, the random walk hypothesis is rejected. However, when double-level change tests are used in the mean and due tolerance is made to various structural breaks, the results are consistent with the random walk hypothesis in most markets. Ali, Shahzad, Raza, and AlYahyaee [15] using MF-DFA analysis, they show that developed markets are relatively more efficient, followed by BRICS stock markets. Comparative analysis of efficiency shows that almost all Islamic stock markets, with the exception of Russia, Jordan and Pakistan, are more efficient than their conventional peers. Pernagallo and Torrisi [16] analyzed whether the behavior of daily profitability of the stock indexes of 12 emerging economies corroborate the hypothesis of "fat tails" and whether these series show long memory. Hurst exponents range from 0.51 to 0.62 showing significant long memories.

Lahmiri, Bekiros, and Bezzina [17], Lahmiri and Bekiros [18] tested the presence of long memories in the stock markets. Lahmiri, Bekiros, and Bezzina [17] show that longterm price fluctuations are persistent, while short-term price fluctuations are anti-persistent. In addition, the level of anti-persistence and the content of information in short-term fluctuations are similar in the four European markets. Lahmiri and Bekiros [18] tested the efficient market hypothesis, in its weak form, on the Casablanca Stock Exchange (CSE), 
Dow Jones and S\&P500 stock markets. The authors show that prices are potentially predictable in the 3 markets and, in all industrial sectors.

Caporale, Gil-Alana, and Poza [19], Milos, Hatiegan, Milos, Barna, and Botoc [20] analyzed the central European stock markets. Caporale, Gil-Alana, and Poza [19] show that these regional markets have high levels of integration, which could call into question portfolio diversification. Milos, Hatiegan, Milos, Barna, and Botoc [20] verified the presence of long memories and long-term correlations, showing that stock markets are not efficient, in their weak form, and have not yet reached a mature stage of development.

In summary, this work aims to contribute to the provision of information to investors and regulators in the stock markets of Eastern Europe, where individual and institutional investors seek diversification benefits, as well as to help promote the implementation of policies that contribute to the efficiency of these markets. Therefore, the aim of this trial is to analyze the impact of the global 2020 pandemic on the memory properties of Eastern European stock markets.

\section{Methodology}

\subsection{Data}

The data used for the preparation of the paper were the prices index (diaries) of the stock markets of CZECH REP, BULGARIA, CROATIA, ESTONIA, LITHUANIA, HUNGARY, POLAND, SLOVAKIA, SLOVENIA, RUSSIA, from 1 January 2016 to 2 September 2020 and the sample was divided in two subperiods: from 1 January 2016 to 30 August 2019 (before Covid) and from 2 September 2019 to 2 September 2020 (Covid-19). The source of the information used was the DataStream platform with local currency quotes to mitigate exchange rate distortions.

\subsection{Methodology}

The development of the research took place through several stages. The characterization of the sample used was performed through descriptive statistics, the adherence test of Jarque and Bera [21] to verify if the data follow a normal distribution. In order to answer the research question, we will use the Detrended Fluctuation Analysis (DFA) methodology, and Detrended Cross-Correlation Analysis ( $p D C C A)$. DFA is an analysis method that examines temporal dependence on non-stationary data series. This technique by assuming that time series are non-stationary avoids spurious results when the analysis focuses on the relationships of the data series in the long term. $D F A$ has the following interpretation: $0<\alpha<0,5$ : anti-persistent series; $\alpha=0,5$ series features random walk; $0,5<\alpha<1$ : persistent series. The function of this technique is to examine the relationship between values $x_{k}$ and $x_{k+t}$ at different moments [22]. The non-trend cross-correlation coefficient $(p D C C A)$ from Zebende [4] is a method to quantify the level of cross-correlation between two non-stationary time series. The coefficient is based on the DFA [23] and DCCA [23] methods. The cross-correlation coefficient depends on the length of the box $S$ (time scale). One of the advantages of this cross-correlation coefficient is centered on the possibility of measuring the correlations between two non-stationary time series at different time scales. The function of this technique is to examine the relationship between values $x_{k}$ and $x_{k+t}$ at different moments [24]. Tables 2 and 3 show the interpretation of exponents $\alpha_{\text {DFA }}$ and pDCCA 
Table 1. Detrended Fluctuation Analysis

\begin{tabular}{cc}
\hline \hline Exponent & Type of signal \\
\hline \hline$\alpha_{\mathrm{DFA}}<0.5$ & long-range anti-persistent \\
$\alpha_{\mathrm{DFA}} \simeq 0.5$ & uncorrelated, white noise \\
$\alpha_{\mathrm{DFA}}>0.5$ & long-range persistent \\
\hline \hline
\end{tabular}

Source: Own processing.

Table 2. Detrended cross-correlation coefficient, $p D C C A$, levels

\begin{tabular}{ccc}
\hline \hline Weak & Medium & Strong \\
\hline \hline$\cong 0.000 \rightarrow \cong 0.333$ & $\cong 0.333 \rightarrow \cong 0.666$ & $\cong 0.666 \rightarrow \cong 1.000$ \\
\hline \hline
\end{tabular}

Source: Own processing.

\section{Results}

Figure 1 shows the evolution, in \% of the differences, of the 10 stock markets in Eastern Europe. In all series, a relatively high dispersion around the mean is noted, as well as a relatively synchronized behavior between the data series. Through graphical analysis, high volatility is observed, especially in January, February and March 2020.

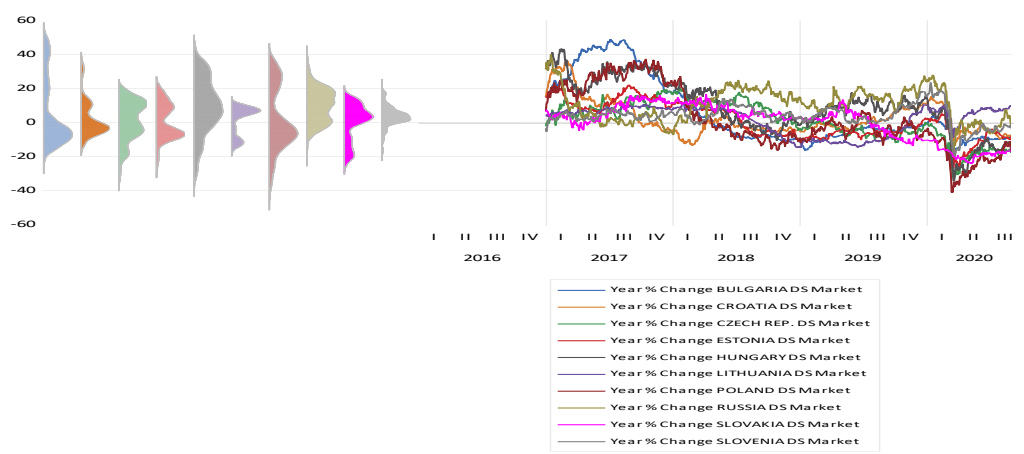

Fig. 1. Evolution, in \% of differences, of the 10 stock markets, in the period from 1 January 2016 to 2 September 2020

Source: Own processing.

Table 3 shows the main descriptive statistics of the ten East European stock markets, yields present positive diary means, with the exception of CZECH REP, POLAND and SLOVAKIA. The HUNGARY market has the highest standard deviation (0.011803), while the LITHUANIA market has the highest level of kurtosis (70.51083) and asymmetry $(-3.432789)$. In addition, the Jarque-Bera test confirms that we are faced with time series that do not follow a normal distribution, evidence confirmed by the levels of asymmetry $(<$ $0)$ and kurtosis (>3). 
Table 3A. Descriptive statistics on profitability of the 5 stock markets from 1 January 2016 to 2 September 2020

\begin{tabular}{lccccc}
\hline \hline & BULGARIA & CROATIA & CZECH REP & ESTONIA & HUNGARY \\
\hline \hline Mean & $6.95 \mathrm{E}-05$ & $3.26 \mathrm{E}-05$ & $-9.64 \mathrm{E}-05$ & $2.32 \mathrm{E}-05$ & 0.000229 \\
Std. Dev. & 0.005066 & 0.005983 & 0.008566 & 0.007335 & 0.011803 \\
Skewness & -2.145286 & -1.497950 & -1.551421 & -4.697442 & -1.507607 \\
Kurtosis & 29.18512 & 16.07891 & 18.42601 & 69.25563 & 18.52451 \\
Jarque-Bera & $35760.87 * * *$ & $9144.195^{* * *}$ & $12575.48^{* * *}$ & $227448.8^{* * *}$ & $12703.09 * * *$ \\
Sum & 0.084769 & 0.039718 & -0.117520 & 0.028329 & 0.278575 \\
Sum Sq. Dev. & 0.031259 & 0.043601 & 0.089366 & 0.065531 & 0.169668 \\
Observations & 1219 & 1219 & 1219 & 1219 & 1219 \\
\hline \hline
\end{tabular}

Source: Own processing.

Table 3B. Descriptive statistics on profitability of the 5 stock markets from 1 January 2016 to 2 September 2020

\begin{tabular}{lccccc}
\hline \hline & LITHUANIA & POLAND & SLOVAKIA & RUSSIA & SLOVENIA \\
\hline \hline Mean & $8.69 \mathrm{E}-05$ & $-6.88 \mathrm{E}-05$ & $-6.47 \mathrm{E}-06$ & 0.000373 & $8.13 \mathrm{E}-05$ \\
Std. Dev. & 0.005160 & 0.011463 & 0.007668 & 0.010603 & 0.007269 \\
Skewness & -3.432789 & -1.457475 & -0.536518 & -1.151359 & -2.258049 \\
Kurtosis & 70.51083 & 20.33156 & 8.716673 & 20.08998 & 33.40669 \\
Jarque-Bera & 233887.9 & 15688.53 & 1718.371 & 15103.92 & 47996.20 \\
Sum & 0.105954 & -0.083915 & -0.007889 & 0.454651 & 0.099117 \\
Sum Sq. Dev. & 0.032434 & 0.160038 & 0.071624 & 0.136931 & 0.064355 \\
Observations & 1219 & 1219 & 1219 & 1219 & 1219 \\
\hline \hline
\end{tabular}

Source: Own processing.

In table 4 we can see the $D F A$ exponents referring to the 10 financial markets of Eastern Europe. Period I regarding the Pre-Covid time scale and we can verify the presence of long memories in the markets BULGARIA (0.54), CROATIA (0.59), ESTONIA (0.55), LITHUANIA (0.59), SLOVENIA (0.55). The CZECH REP. (0.41), HUNGARY (0.44), POLAND (0.46), SLOVAKIA (0.36), RUSSIA (0.48) markets show signs of antipersistence, i.e. the presence of short-term memories. In period II the covid-19-time scale is contained, and we found that the exponents Detrended Fluctuation Analysis (DFA) range from 0.64 to 0.75 , showing significant long memories in all markets, except for the SLOVAKIA market (0.45). These findings show that prices do not fully reflect the information available and that price changes are not i.i.d. This situation has implications for investors, as some profitability can be expected, creating opportunities for arbitration and abnormal income. These results are corroborated by the authors Lahmiri and Bekiros [18], Milos, Hatiegan, Milos, Barna, and Botoc [20] who evidence long memories in the profitability of the stock markets. 
Table 4. DFA exponent for index and return. The values of the linear adjustments for $\alpha$ DFA always had R2 $>0.99$

\begin{tabular}{lcc}
\hline \multicolumn{1}{c}{ Stock market } & DFA exponent (before crisis) & DFA exponent (Covid period) \\
\hline \hline CZECH REP. DS Market & $0.41 \cong 0.0039$ & $0.68 \cong 0.0024$ \\
BULGARIA DS Market & $0.54 \cong 0.0076$ & $0.74 \cong 0.0074$ \\
CROATIA DS Market & $0.59 \cong 0.0058$ & $0.72 \cong 0.0012$ \\
ESTONIA DS Market & $0.55 \cong 0.0008$ & $0.73 \cong 0.0049$ \\
LITHUANIA DS Market & $0.59 \cong 0.0003$ & $0.64 \cong 0.0062$ \\
HUNGARY DS Market & $0.44 \cong 0.0011$ & $0.65 \cong 0.0007$ \\
POLAND DS Market & $0.46 \cong 0.0097$ & $0.66 \cong 0.0034$ \\
SLOVAKIA DS Market & $0.36 \cong 0.0041$ & $0.45 \cong 0.0039$ \\
SLOVENIA DS Market & $0.55 \cong 0.0056$ & $0.75 \cong 0.0011$ \\
RUSSIA DS Market & $0.48 \cong 0.0041$ & $0.71 \cong 0.0012$ \\
\hline \hline
\end{tabular}

Note: The hypotheses are $H_{0}: \alpha=0.5$ and $H_{1}: \alpha \neq 0.5$.

Source: Own processing.

Table 5 shows the Detrended cross-correlation coefficient for $p D C C A$ period from January 1, 2016 to September 2, 2020. Period I comprises the time lapse from January 1, 2016 to August 30, 2019 (Pre-Covid), and we can verify that rhoDCCA shows 28 crosscorrelation coefficients trendless $\left(\lambda_{\mathrm{DCCA}}\right)$ weak $(\cong 0.000 \rightarrow \cong 0.333)$, and 17 medium correlation coefficients $(\cong 0.333 \rightarrow \cong 0.666)$, in 45 possible pairs. When we analyzed period II (Covid) we found 36 cross-correlation coefficients trendless $\left(\lambda_{\text {DCCA }}\right)$ strong $(0.666$ $\rightarrow \cong 1,000)$, and 9 weak correlation coefficients $(\cong 0.000 \rightarrow \cong 0.333)$. When compared the 2 subperiods we found 41 pairs of markets cross-correlation coefficients trendless $\left(\lambda_{\text {DCCA }}\right)$ strong (out of 45 possible), and 4 pairs of markets decreased rhoDCCA, namely ESTONIA-SLOVAKIA, LITHUANIA-SLOVAKIA, HUNGARY-SLOVAKIA, POLAND-SLOVAKIA. These findings show that the stock markets analyzed have high levels $r h o D C C A$, which may question the hypothesis of efficient portfolio diversification.

Table 5. Summary table of coefficients, pDCCA referring to the 10 stock markets, in the period from $01 / 01 / 2016$ to $02 / 09 / 2020$

\begin{tabular}{lccccc}
\hline \hline & & \multicolumn{2}{c}{$\rho$ DCCA (before Covid-19) } & (Covid-19) & \\
\hline \hline \multicolumn{1}{c}{ Index } & pDCCA & Time scale (days) & $p D C C A$ & $\begin{array}{c}\text { Time scale } \\
\text { (days) }\end{array}$ & Tendência \\
\hline \hline CZECH REP. / BULGARIA & $\mathbf{0 . 1 3}$ & $\mathrm{n}>236$ days & 0.91 & $\mathrm{n}>64$ days & $\uparrow$ \\
CZECH REP. / CROATIA & $\mathbf{0 . 1 9}$ & $\mathrm{n}>102$ days & 0.88 & $\mathrm{n}>60$ days & $\uparrow$ \\
CZECH REP. / ESTONIA & $\mathbf{0 . 2 6}$ & $\mathrm{n}>66$ days & 0.86 & $\mathrm{n}>56$ days & $\uparrow$ \\
CZECH REP. / LITHUANIA & 0.34 & $\mathrm{n}>138$ days & 0.85 & $\mathrm{n}>64$ days & $\uparrow$ \\
CZECH REP. / HUNGARY & 0.42 & $\mathrm{n}>22$ days & 0.88 & $\mathrm{n}>56$ days & $\uparrow$ \\
CZECH REP. / POLAND & 0.41 & $\mathrm{n}>187$ days & 0.87 & $\mathrm{n}>64$ days & $\uparrow$ \\
CZECH REP. / SLOVAKIA & $\mathbf{0 . 0 3}$ & $\mathrm{n}>166$ days & $\mathbf{0 . 2 3}$ & $\mathrm{n}>64$ days & $\uparrow$ \\
CZECH REP. / SLOVENIA & 0.36 & $\mathrm{n}>210$ days & 0.93 & $\mathrm{n}>64$ days & $\uparrow$ \\
\hline \hline
\end{tabular}




\begin{tabular}{|c|c|c|c|c|c|}
\hline CZECH REP. / RUSSIA & 0.28 & $\mathrm{n}>14$ days & 0.83 & $\mathrm{n}>62$ days & $\uparrow$ \\
\hline BULGARIA / CROATIA & 0.08 & $\mathrm{n}>210$ days & 0.89 & $\mathrm{n}>64$ days & $\uparrow$ \\
\hline BULGARIA / ESTONIA & 0.29 & $\mathrm{n}>236$ days & 0.86 & $\mathrm{n}>60$ days & $\uparrow$ \\
\hline BULGARIA / LITHUANIA & 0.10 & $\mathrm{n}>26$ days & 0.80 & $\mathrm{n}>58$ days & $\uparrow$ \\
\hline BULGARIA / HUNGARY & 0.15 & $n>236$ days & 0.86 & $\mathrm{n}>60$ days & $\uparrow$ \\
\hline BULGARIA / POLAND & 0.42 & $\mathrm{n}>42$ days & 0.81 & $\mathrm{n}>64$ days & $\uparrow$ \\
\hline BULGARIA / SLOVAKIA & 0.06 & $\mathrm{n}>156$ days & 0.28 & $\mathrm{n}>64$ days & $\uparrow$ \\
\hline BULGARIA / SLOVENIA & 0.11 & $\mathrm{n}>85$ days & 0.90 & $\mathrm{n}>62$ days & $\uparrow$ \\
\hline BULGARIA / RUSSIA & 0.19 & $\mathrm{n}>75$ days & 0.80 & $\mathrm{n}>60$ days & $\uparrow$ \\
\hline CROATIA / ESTONIA & 0.35 & $\mathrm{n}>166$ days & 0.84 & $\mathrm{n}>64$ days & $\uparrow$ \\
\hline CROATIA / LITHUANIA & 0.28 & $\mathrm{n}>166$ days & 0.79 & $\mathrm{n}>58$ days & $\uparrow$ \\
\hline CROATIA / HUNGARY & 0.17 & $\mathrm{n}>176$ days & 0.83 & $\mathrm{n}>64$ days & $\uparrow$ \\
\hline CROATIA / POLAND & 0.19 & $\mathrm{n}>147$ days & 0.87 & $\mathrm{n}>64$ days & $\uparrow$ \\
\hline CROATIA / SLOVAKIA & 0.11 & $\mathrm{n}>198$ days & 0.20 & $\mathrm{n}>64$ days & $\uparrow$ \\
\hline CROATIA / SLOVENIA & 0.35 & $\mathrm{n}>138$ days & 0.93 & $\mathrm{n}>62$ days & $\uparrow$ \\
\hline CROATIA / RUSSIA & 0.33 & $\mathrm{n}>223$ days & 0.80 & $\mathrm{n}>64$ days & $\uparrow$ \\
\hline ESTONIA / LITHUANIA & 0.44 & $\mathrm{n}>187$ days & 0.84 & $\mathrm{n}>56$ days & $\uparrow$ \\
\hline ESTONIA / HUNGARY & 0.36 & $\mathrm{n}>210$ days & 0.83 & $\mathrm{n}>64$ days & $\uparrow$ \\
\hline ESTONIA / POLAND & 0.35 & $\mathrm{n}>198$ days & 0.77 & $\mathrm{n}>64$ days & $\uparrow$ \\
\hline ESTONIA / SLOVAKIA & 0.40 & $\mathrm{n}>223$ days & 0.14 & $n>64$ days & $\downarrow$ \\
\hline ESTONIA / SLOVENIA & 0.36 & $\mathrm{n}>138$ days & 0.87 & $\mathrm{n}>64$ days & $\uparrow$ \\
\hline ESTONIA / RUSSIA & 0.31 & $\mathrm{n}>198$ days & 0.72 & $\mathrm{n}>64$ days & $\uparrow$ \\
\hline LITHUANIA / HUNGARY & 0.11 & $\mathrm{n}>108$ days & 0.69 & $\mathrm{n}>45$ days & $\uparrow$ \\
\hline LITHUANIA / POLAND & 0.26 & $\mathrm{n}>130$ days & 0.79 & $\mathrm{n}>60$ days & $\uparrow$ \\
\hline LITHUANIA / SLOVAKIA & 0.32 & $\mathrm{n}>166$ days & 0.12 & $n>64$ days & $\downarrow$ \\
\hline LITHUANIA / SLOVENIA & 0.53 & $\mathrm{n}>236$ days & 0.83 & $\mathrm{n}>64$ days & $\uparrow$ \\
\hline LITHUANIA / RUSSIA & 0.16 & $\mathrm{n}>130$ days & 0.76 & $\mathrm{n}>64$ days & $\uparrow$ \\
\hline HUNGARY / POLAND & 0.53 & $\mathrm{n}>96$ days & 0.80 & $\mathrm{n}>62$ days & $\uparrow$ \\
\hline HUNGARY / SLOVAKIA & 0.22 & $\mathrm{n}>122$ days & 0.19 & $\mathrm{n}>58$ days & $\downarrow$ \\
\hline HUNGARY / SLOVENIA & 0.20 & $\mathrm{n}>90$ days & 0.85 & $\mathrm{n}>62$ days & $\uparrow$ \\
\hline HUNGARY / RUSSIA & 0.29 & $\mathrm{n}>236$ days & 0.81 & $\mathrm{n}>48$ days & $\uparrow$ \\
\hline POLAND / SLOVAKIA & 0.18 & $n>236$ days & 0.08 & $n>62$ days & $\downarrow$ \\
\hline POLAND / SLOVENIA & 0.46 & $\mathrm{n}>122$ days & 0.86 & $\mathrm{n}>64$ days & $\uparrow$ \\
\hline POLAND / RUSSIA & 0.49 & $\mathrm{n}>14$ days & 0.87 & $\mathrm{n}>62$ days & $\uparrow$ \\
\hline SLOVAKIA / SLOVENIA & 0.12 & $\mathrm{n}>147$ days & 0.20 & $\mathrm{n}>64$ days & $\uparrow$ \\
\hline SLOVAKIA / RUSSIA & $\mathbf{0 . 1 0}$ & $\mathrm{n}>130$ days & 0.16 & $\mathrm{n}>36$ days & $\uparrow$ \\
\hline SLOVENIA / RUSSIA & 0.15 & $\mathrm{n}>20$ days & 0.80 & $\mathrm{n}>64$ days & $\uparrow$ \\
\hline
\end{tabular}

Source: Own processing. 


\section{Conclusion}

The overall conclusion to be withheld and sustained in the results obtained, through tests carried out with econophysical models, shows that the global pandemic has a significant impact on the adjustment of the financial markets of Eastern Europe. The results indicate that these regional markets have significant persistence during the Covid period, which motivates some arbitrage opportunities. Additionally, Detrended cross-correlation coefficient $p D C C A$ increased in the Covid period when compared to the previous subperiod, which may call into question the hypothesis of portfolio diversification. These findings also make room for market regulators to take steps to ensure better information among international financial markets. In conclusion, we consider that investors should diversify their portfolios, and invest in less risky markets, with the purpose of mitigating risk and improving the efficiency of their portfolios.

\section{References}

1. M. T. S. G.Sudha, V.Sornaganesh, "IMPACT OF INDIAN STOCK MARKET DUE TO CRISIS IN MARCH 2020,” 2020.

2. R. Dias, J. V. da Silva, and A. Dionísio, "Financial markets of the LAC region: Does the crisis influence the financial integration?," Int. Rev. Financ. Anal., 63, (February), 160-173 (2019).

3. M. Gallegati, "Beyond econophysics (not to mention mainstream economics)," Eur. Phys. J. Spec. Top. (2016).

4. G. F. Zebende, "DCCA cross-correlation coefficient: Quantifying level of crosscorrelation," Phys. A Stat. Mech. its Appl., 390, (4), 614-618 (2011).

5. V. Filipovski and D. Tevdovski, "Stock market efficiency in south eastern Europe: Testing return predictability and calendar effects," in Regaining Global Stability After the Financial Crisis (2018).

6. P. Ferreira, "Long-range dependencies of Eastern European stock markets: A dynamic detrended analysis," Phys. A Stat. Mech. its Appl (2018).

7. H. Muharam, W. Mawardi, E. D. Arfinto, and Najmudin, "Volatility spillovers under difference in the degree of market integration: Evidence from the selected asian and eastern European stock markets," J. Int. Stud (2019).

8. S. Moagar-Poladian, D. Clichici, and C. V. Stanciu, "The comovement of exchange rates and stock markets in Central and Eastern Europe," Sustain. (2019).

9. Lawrence H. Summers, "Does the stock market rationally reflect fundamental values," J. Finance (1986).

10. S. Nisar and M. Hanif, "Testing weak form of efficient market hypothesis: Empirical evidence from South-Asia," World Appl. Sci. J. (2012).

11. S. Mehla and S. K. Goyal, "Empirical Evidence on Weak Form of Efficiency in Indian Stock Market," Asia-Pacific J. Manag. Res. Innov. (2013).

12. A. El Khamlichi, K. Sarkar, M. Arouri, and F. Teulon, "Are Islamic equity indices more efficient than their conventional counterparts? Evidence from major global index families," J. Appl. Bus. Res. (2014).

13. D. Li, Y. Nishimura, and M. Men, "The long memory and the transaction cost in financial markets," Phys. A Stat. Mech. its Appl. (2016).

14. G. Ngene, K. A. Tah, and A. F. Darrat, "The random-walk hypothesis revisited: new evidence on multiple structural breaks in emerging markets," Macroecon. Financ. Emerg. Mark. Econ. (2017).

15. S. Ali, S. J. H. Shahzad, N. Raza, and K. H. Al-Yahyaee, "Stock market efficiency: A comparative analysis of Islamic and conventional stock markets," Phys. A Stat. Mech. 
its Appl. (2018).

16. G. Pernagallo and B. Torrisi, "An empirical analysis on the degree of Gaussianity and long memory of financial returns in emerging economies," Phys. A Stat. Mech. its Appl. (2019).

17. S. Lahmiri, S. Bekiros, and F. Bezzina, "Multi-fluctuation nonlinear patterns of European financial markets based on adaptive filtering with application to family business, green, Islamic, common stocks, and comparison with Bitcoin, NASDAQ, and VIX," Phys. A Stat. Mech. its Appl. (2020).

18. S. Lahmiri and S. Bekiros, "Nonlinear analysis of Casablanca Stock Exchange, Dow Jones and S\&P500 industrial sectors with a comparison," Phys. A Stat. Mech. its Appl. (2020).

19. G. M. Caporale, L. A. Gil-Alana, and C. Poza, "High and low prices and the range in the European stock markets: A long-memory approach," Res. Int. Bus. Financ. (2020).

20. L. R. Milos, C. Hatiegan, M. C. Milos, F. M. Barna, and C. Botoc, "Multifractal detrended fluctuation analysis (MF-DFA) of stock market indexes. Empirical evidence from seven central and eastern european markets," Sustain. (2020).

21. C. M. Jarque and A. K. Bera, "Efficient tests for normality, homoscedasticity and serial independence of regression residuals," Econ. Lett., 6 ( 3), 255-259 (1980).

22. E. F. Guedes et al., "Statistical test for $\triangle \rho D C C A$ : Methods and data," Data Br. (2018).

23. C. K. Peng, S. V. Buldyrev, S. Havlin, M. Simons, H. E. Stanley, and A. L. Goldberger, "Mosaic organization of DNA nucleotides," Phys. Rev. E, 49 (2), 16851689 (1994).

24. B. Podobnik and H. E. Stanley, "Detrended cross-correlation analysis: A new method for analyzing two nonstationary time series," Phys. Rev. Lett., 100, (8), (2008).

25. P. Ferreira, A. Dionísio, E. F. Guedes, and G. F. Zebende, "A sliding windows approach to analyse the evolution of bank shares in the European Union," Phys. A Stat. Mech. its Appl., 490, 1355-1367 (2018). 